http://dx.doi.org/10.19183/how.24.2.330

\title{
Use of the Genre-Based Approach to Teach Expository Essays to English Pedagogy Students
}

\section{El uso de un enfoque basado en géneros lingüísticos para enseñar ensayos expositivos a estudiantes universitarios de pedagogía del inglés*}

\author{
Eric Gómez Burgos \\ egomez@utalca.cl \\ Universidad de Talca, Linares, Chile
}

The following article reports the results of an action research project conducted in a public university in Chile. The project consisted of exposing ten undergraduate students from an English pedagogy program to a genre-based approach to writing expository essays. During eight weeks the three stages of the genre-based approach, namely: deconstruction, joint construction, and individual construction, were adapted and developed with the participants. Results gave evidence that a genrebased approach to teaching expository essays is effective in this context because after the application of the action research project, the students' compositions improved in comparison to the participants' pre-intervention essays.

Key words: Chile, English as a foreign language, expository essay, genre-based approach, university.

Este artículo informa sobre los resultados de una investigación acción en una universidad chilena, que consistió en exponer a diez estudiantes de pedagogía en inglés a un enfoque basado en géneros para escribir ensayos expositivos. Durante ocho semanas las tres etapas del enfoque basado en géneros: deconstrucción, construcción conjunta y construcción individual se adaptaron y desarrollaron con los

Received: August 11, 2016. Accepted: March 30, 2017.

How to cite this article (APA 6th ed.):

Gómez Burgos, E. (2017). Use of the genre-based approach to teach expository essays to English pedagogy students. HOW, 24(2), 141-159. http://dx.doi.org/10.19183/how.24.2.330.

This article is licensed under a Creative Commons Attribution-NonCommercial-NoDerivatives 4.0 International License. License Deed can be consulted at http://creativecommons.org/licenses/by-nc-nd/4.0/. 
estudiantes. Los resultados evidencian que un enfoque basado en géneros es eficaz en un ambiente de inglés como lengua extranjera, dado que tras la intervención los textos de los estudiantes mejoraron en comparación a los ensayos previos a la intervención.

Palabras clave: Chile, enfoque basado en géneros lingüísticos, ensayos expositivos, inglés como lengua extranjera, universidad.

\section{Introduction}

During the last decades writing has been reported to be one of the most complex activities students deal with in the process of learning the first and second language (Nunan, 1999). Educational policies in countries like Chile place emphasis on the insertion of writing activities in the first language (L1) curriculum from the earliest stages of the educational system as evidenced in its curriculum framework (MINEDUC, 2012). In second or foreign language environments, writing becomes even more complicated. In Chile, research has shown that English as a foreign language (EFL) learners do not have the academic literacies required to be successful at university (Arancibia Aguilera, 2014). Therefore, the poor development of academic literacies in students' mother tongue is claimed to be transferred to the second/foreign language (L2) learning process; consequently, writing becomes a more complex process in foreign language contexts.

Chile legislated English as the compulsory foreign language from 5th grade elementary education to 12 th grade in secondary education more than 20 years ago; nonetheless, results in terms of the use of the target language have been reported to be very basic. According to the last administration of the SIMCE ${ }^{1}$ examination in 2014, students do not achieve high requirements of proficiency in English when they finish secondary education; results showed that students achieved 51 points out of 100 , which means that $53 \%$ of Chilean 11 th graders achieved less than A1 level in English. These results are similar to the ones illustrated by Education First (2013) where Chile was ranked 44 out of 60 countries, in the category "very low proficiency".

In light of the previous information, the scenario for tertiary-level preparation in academic literacies in L2 contexts seems to be complex in Chile. To my knowledge, students who start university studies lack awareness of meaning-making choices or resources that exist to be instantiated in written genres. In this regard, they are not able to communicate successfully in specific situations and audiences in the foreign language, as they do not have the "linguistic resources for organizing their meaning and selecting particular words that are

SIMCE stands for "Sistema de Medición de la Calidad de la Educación", which is a standardised test applied throughout Chile in different grades in order to measure the students' proficiency in different areas of knowledge. 
maximally appropriate to the context" (Yasuda, 2015, p. 106). On this point, writing in L2 becomes a difficult task students have to face at the tertiary level.

Besides, if we add that investigations have stated that certain approaches or teachers' methodologies used to teach writing at the tertiary level are considered inadequate and do not address particular aspects of students' writing needs (Hyland, 2002; Wingate, 2006; Yasuda, 2015), writing preparation is needed and its development is a fundamental issue to tackle in the second or foreign language environment.

The above situation concerning the inadequateness of teaching methodologies, student writing needs and previous preparation in L2 writing was observed at a public university in Chile where the syllabi of L2 academic writing courses stated that students had to produce different types of genres using a cognitive approach. Many cognitive models conceptualize writing from the mind, ignoring that writing is a social activity; that is to say, they lack exposure to genres taken from an authentic environment to provide students with real contexts. In order to tackle the recently explained situation, an action research project based on a genrebased approach was conducted. In so doing, this paper provides an overview of the sociosemiotic perspective towards teaching writing in EFL settings, placing emphasis on the genrebased approach to teaching writing in EFL contexts, then, it concentrates on the genre of the expository essay and provides samples of the pedagogical intervention in the field.

\section{Socio-Semiotic Perspective Towards Teaching Writing}

Halliday and Hasan (1985), Halliday and Matthiessen (2004), and Matthiessen (2009) define language as a system of meaning potentials, that is, an infinite number of options individuals have in order to select specific meanings to perform different social activities (Bloor \& Bloor, 2004; Gómez Burgos, 2015). This potential allows people to choose the meanings that are appropriate to the social roles enacted in different situations.

Based on the above conceptualization of language, writing represents an opportunity to scaffold the students with resources for making meaning, as texts are the results of meaning potentials writers create and convey in the community, and the support students receive before the writing task per se; this process is essential to identify common patterns used in the specific community texts belong to. In so doing, writers should bear in mind the social context in which the different texts are used since written production, as Chala and Chapetón (2013) asserted, entails more than the development of mechanical skills. Written production demands continuous exchange of information and negotiations of ideas conveyed between the writer's own personal experience and the target reader. Consequently, writing is a social and cultural activity; that is, when you write, you communicate ideas, feelings, and/or opinions situated within a social and cultural context. 
Writing is therefore a complex process (McCutchen, 2011, Nunan, 1999) that demands the development of meaning-making choices not only for L2 or foreign language learners but for everyone. Regarding that complexity, different models of writing instruction have appeared, and it is the genre-based approach that best fits the conceptualization presented in the previous paragraph as it defines writing as a social activity as well. This approach has received increased attention in the last 20 years (Brisk, 2015; Hyland, 2007; Hyon, 1996; Paltridge, 1996, 2001) as genre-based approaches have focused on functional language, i.e., the language that occurs in particular socio-cultural contexts; therefore, people fulfill certain functions such as responding to a request or asking for information by using particular genres like letters, emails, and editorials, to name a few.

The genre "represents the norms of different kinds of writing" (Harmer, 2001, p. 327) being conveyed and determined by social contexts (Knapp \& Watkins, 2005). Therefore, a genre-based approach to teaching writing is presented as a challenging model to use in the classroom because it "refers to pedagogy that involves examining and deconstructing examples of genres (categories of text)" (Bruce, 2008, p. 6). At the same time, learners follow some stages, namely: deconstruction, joint construction, and individual construction (Rose \& Martin, 2012), when dealing with the process of writing in order to negotiate meanings through writing.

\section{Describing Expository Essays From a Socio-Semiotic Perspective}

The macro genre of argumentation is a crucial field to be considered at the tertiary level. To my knowledge, its inclusion in the curricula of many programs and courses falls not only in writing courses but also in humanities and social sciences courses because of its importance in the development of discourse competence in university students. For that reason, textbooks to be used by students at this level include examples of argumentative texts (Ramage, Callaway, Clary-Lemon, \& Waggoner, 2009) to either develop or improve the students' argumentative skills.

The development of arguments entails a complex process since this activity involves higher-order thinking skills in comprehension, analysis, and problem solving. For this complexity, many students have difficulties when shaping arguments in their essays (Bacha, 2010; Davies, 2008; Wingate, 2012). Ferretti, Andrews-Weckerly, and Lewis (2007) stated that argumentative essays produced by the participants in their study contained critical elements and few supporting reasons, particularly when the use of genre specifications, or features of the genres, are either not taught or taught inappropriately; that is to say, sometimes students are not presented with model texts and thus do not have previous contact with the genre specification. Similarly, Díaz (2002) pointed out that argumentative essays deal 
with controversial topics where the authors defend their own points of view based on their knowledge.

According to Knapp and Watkins (2005), Martin and Rose (2007), and Rose and Martin (2012), an argument (or argumentation) is subdivided into two main genres: exposition and discussion. The first type, exposition, corresponds to arguing from one point of view while the second one, discussion, occurs when "two or more points of view are presented and one argued for over the other" (Martin \& Rose, 2007, p. 12).

For this study, I will focus on the genre of exposition described by Rose and Martin (2012). The authors suggested a pathway of genre development where the schematic structure that writers need to follow was presented. The moves of the genre were classified into Thesis, Arguments, and Restatement (summarized in Figure 1).

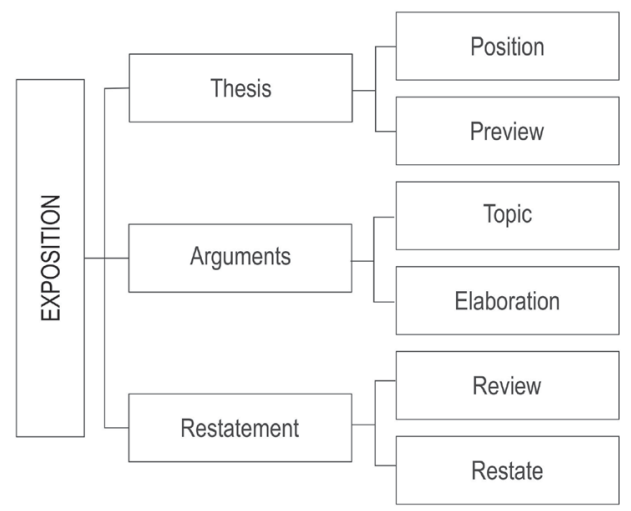

Figure 1. Genre of Expository Essay (Adapted From Rose \& Martin, 2012)

Figure 1 shows the schematic structure of the genre of exposition. This genre is organized into three main stages that represent the flow of information in the development of arguments. These stages are subdivided into different moves or sub-steps to make the text coherent; that is, information is clear and easy to be followed by the intended audience and it focuses on a particular topic. Students need to consider these stages because they form the basis for developing this genre coherently.

\section{Teaching Expository Essays in EFL Settings}

As stated above, the genre-based approach provides the learners with socio-cultural conventions about the particularities of different genres. There are two main principles of this approach; first, the texts incorporate not only aspects of discourse but also contextual 
features (Paltridge, 2001); second, the text clearly considers the way genres are shaped and how to achieve their particular communicative goals (Bhatia, 1993; Paltridge, 2001).

Considering Feez (1998), Bhatia (2004), Bawarshi and Reiff (2010), and Rose and Martin (2012), three stages of genre-based approach can be identified:

1. The first stage is the deconstruction phase, which is very useful to prepare the students to write their expository essays. In this stage, reading about the topic is used in the classroom in order to "build the field for subsequent writing as well as providing models for persuasive writing” (Rose \& Martin, 2012, p. 201). Students are invited to take notes and underline the text to identify key elements, the lexico-grammar patterns, and so on. Following this stage, students are asked to focus on aspects that make up discourse in the text. Learners have to analyze the lexico-grammatical aspects within the text so as to get resources to make meaning as text.

2. The second stage, the joint construction, starts with a brainstorming of the students' different characteristics obtained from the analysis of the text in the previous stage. The teacher needs to support the students' development of their ideas in order to motivate them to write the text in groups. Students are elicited to participate in the joint construction and give their opinions about the aspects of the genre being constructed.

3. Finally, the third stage corresponds to the individual construction, where the students start the development of their own texts. In this process, the teacher is always monitoring and attentive to the students' doubts. The collaboration of classmates when revising or editing drafts is always important.

The above stages are considered relevant in the process of teaching writing in a foreign language class because they follow the necessary steps to model, deconstruct, and construct texts regarding a genre-based approach. Additionally, in EFL classrooms, learners need to be provided with opportunities to identify the schematic structures and situational contexts in which genres are developed as most of the time the genres being constructed are not accessible for students.

\section{Description and Explanation of the Pedagogical Experience}

This investigation adheres to the principles of action research and presents a qualitative approach to the reality observed: in this case, the use of a genre-based approach to tackle the teaching of expository essays. The genre of expository essays was chosen because the inclusion of argumentation in university courses is one of the central elements of instruction both in Spanish and English curricula in most universities in Chile. 


\section{Participants}

A group of 10 undergraduate students in their third year from an English Pedagogy Program offered by a public university in Chile was exposed to a methodology centered on a genre-based approach to teach writing. Participants were eight women (age range was 20-23 years old) and two men (19 and 21 years old). The students took a TOEIC ${ }^{2}$ mock test applied before the application of this action research project, and based on their results on this test, the majority of the students were labeled as upper-intermediate in English.

\section{Instruments}

The material used in this case study consisted of (a) written tasks and (b) the instructor's $\log$ entries. The students wrote four expository essays on different issues related to educational topics; however, for this study only the diagnostic task and the post-intervention task are considered. The diagnostic task was a writing activity where the students wrote about the topic "an inclusive education approach can be implemented in Chilean schools"; then, the written task after the intervention was based on the topic "I consider education in Chile to be good". The researcher, who was the teacher of the class, was in charge of completing the log entries after each lesson to record his impressions and perceptions about the implementation.

\section{Procedure}

The period of instruction consisted of eight sessions of 90 minutes where teaching followed three main stages adapted from Feez (1998), Bhatia (2004), Bawarshi and Reiff (2010), and Rose and Martin (2012), namely: deconstruction, joint construction, and individual construction, paying special attention to the characteristics of the genre of expository essays (Rose \& Martin, 2012).

The first class was the application of a diagnostic measure where the participants wrote their essays without previous exposure to the instructional methodology. The second and third sessions consisted of negotiation and deconstruction of the elements in the model text. This text was analyzed by the instructor and the participants in order to reinforce the students' discovery of the resources in the text. The fourth and fifth classes were the joint stage concerning the topic "Education in Chile is equitable" where students developed their thesis and the outline of the essays. The sixth and seventh classes were the individual constructions; here the students finished their essays. The eighth class was the deconstruction and negotiation of another text, then the joint construction and outline of the opinion essay

TOEIC stands for Test of English for International Communication. This test is used as a diagnostic test to measure the students' previous knowledge in the program. 
about the topic "I consider education in Chile to be good" where the students worked on the individual construction of their final essays. Data analysis followed the socio-semiotic analysis explained by Martin and Rose (2007).

\section{Results on Implementation}

The main findings from the pedagogical implementation and the comparison of the participants' expository essays written before and after the intervention are shown below.

\section{Deconstruction Stage}

As stated previously, the first session corresponded to the deconstruction stage where a text used as a model was analyzed based on the sub-process within the stage. The model text was a written exposition in the form of an editorial because the model text needs to be authentic and show evidence of the stages of the genre. Based on these criteria, this was the best text found considering that the theme had to be related to the unit the teacher wanted to convey with the students. Figure 2, taken from the teacher's Logbook 1, shows the sequence of activities in the deconstruction stage.

1. A real written exposition is presented to the students who are asked to read it and analyse it.

2. The students are asked to answer questions in order to model context of culture, situation, and text features; the students identify the social purpose, the audience, and particular language features.

3. The students are presented with different parts of the schematic structure of a written exposition with its different moves using the model text.

Figure 2. Sequence of Activities in Deconstruction

Figure 2 shows the sequence of activities in the first part of a genre-based lesson: the deconstruction. Based on that information, I can conclude that the role of the teacher in the deconstruction stage is necessary because he has to encourage the students to analyze the text by means of eliciting them to participate in the discussion. This first phase is essential since students develop knowledge and skills about the particularities of the text being deconstructed and therefore learners form a basis for the next step, where they start the construction of the genre. According to Rose and Martin (2012), teachers' feedback is very important while students are in contact with real models of the genre. The teacher has to give specific explanation about the genre under construction, the stages and moves within the text. 
The teacher also has to model the genre using questions about the main text such as:

- Who's the author?

- Who is the intended audience?

- What are the characteristics of the text?

- Which parts of the text can be identified?

- What characteristics of language can be identified?

From the previous perspective, the supportive role of the teacher emerges and is represented by the way he conducted the analysis of the model text.

In order to show students the characteristics of the text, the students and the teacher performed the analysis regarding the stages in the model text, as summarized in Figure 3.

As indicated in Figure 3, the analysis showed that the schematic structure of the text was followed clearly because the author negotiated meaning following the appropriate moves of the genre. It means that the genre had the three stages: Thesis, Arguments, and a Restatement.

The stage of deconstruction is essential in developing argumentative skills in learners because they have to negotiate meaning concerning the genre being analyzed. As Rose and Martin (2012) stated, the deconstruction stage is crucial because the teacher and learners are "consolidating guidelines" (p. 71) about how to write a written exposition, which takes place in the next stages of construction.

\section{Joint Construction Stage}

After students deconstructed the model text, the teacher started with the next stage, namely, joint construction stage, where the new field of experience is built up. As Rose and Martin (2012) pointed out, the teacher has to initiate the joint construction in order to encourage the students to organize their ideas in-group and to cooperate in the discussion. In this intervention, the teacher guided learners in this process of joint-construction and wrote the results of this phase on the board to allow all the participants to be part of the activity. The sequence of these activities is shown in Figure 4.

In the sequence of activities shown in Figure 4, the teacher's role is relevant because he has to negotiate different parts of the genre being constructed with his students by means of questions and group discussion. Therefore, these interactions (students-teacher) give students opportunities to feel more confident about the writing process.

Similarly, writing collaboratively (students writing together) makes the task easier for students (Rose \& Martin, 2012) and they see the teacher as a support. After students' comments, analysis, and discussions are gathered, the text is jointly constructed and ready to 


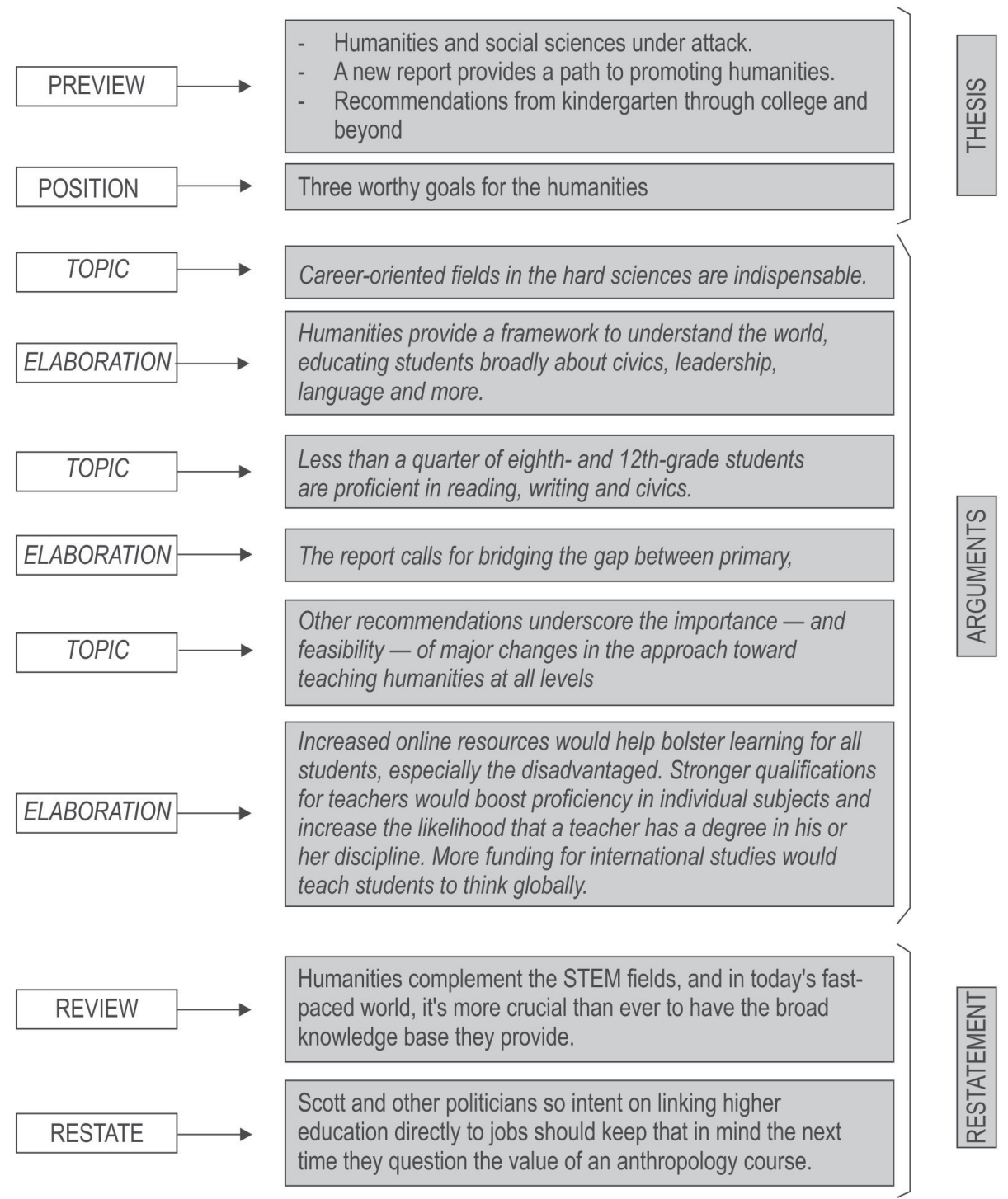

Figure 3. Schematic Structure in Model Text 
1. Students make comments about the previous lesson.

2. Students discuss the topic being analysed in groups of two or three.

3. Teacher writes on the board the students' comments.

4. Students make an outline of their opinion essays about the topic and start writing the first draft in groups.

5. Teacher monitors students' work.

6. Students are required to write the first paragraph (thesis) paying attention to the different moves and sequences of the genre of exposition discussed in the previous lesson.

7. Teacher checks the students' progress and makes corrections on the board.

8. Students are asked to research more information about the topic to tackle the main issue (as homework).

Figure 4. Sequence of Activities (Joint Construction Stage)

be published. The final text achieves the characteristics of the genre of the exposition, that is, it has the three moves (thesis, argument, restatement), and the lexico-grammatical aspects of language are related to the genre and the intended audience. This is so because the joint construction followed the stages explained earlier and collaboration among the students was a positive resource to support the final text.

\section{Individual Construction}

When the joint construction is ready, the last stage of this approach takes place: the individual construction. In this phase, the students are free to write their expositions, in the form of an expository essay, regarding the topic being assigned or commonly agreed upon. Similar to the previous stages, the teacher needs to monitor the students' development of their texts; however, learners are likely to be more confident to write their own texts as they had been practicing.

In this final stage, learners need to start with previous knowledge about their own research related to the assigned topic to construct the field of experience similar to what they did in the joint construction. Students follow the process of composition from outline to drafts and drafts to final product. After that, they revise and edit their writing and then hand it in or publish it.

\section{Results on Participants' Expository Essays}

In general terms, the pre-intervention essays seem to be expository essays as data showed that some of the essays followed the schematic structures of the genre better than 
others. This is to say, some essays included the three stages given by Rose and Martin (2012) and Martin and Rose (2007), namely, Thesis, Arguments and Restatement and their moves in each stage; however, the majority lacked a move in the different stages of the text.

Concerning the flow of information in the paragraphs, the analysis showed that the pre-intervention essays contained a Thesis. Two essays had the Thesis of the expository essay with the two parts, namely: preview and position, contained in one paragraph. Three essays had three paragraphs as the Thesis of the expository essay; the author presented data as a preview in the first and second paragraphs and the position was shown in the third paragraph. Finally, five essays did not include one of the moves of the Thesis. Figure 5 shows an example of the Thesis of a pre-intervention essay.

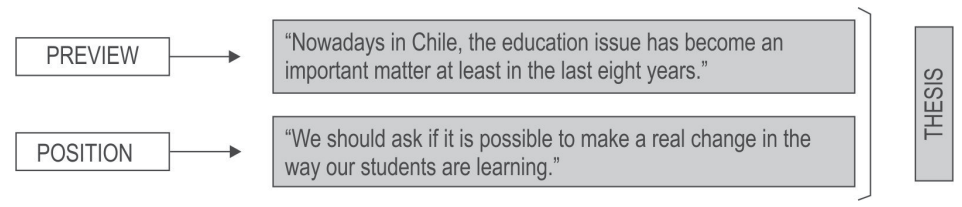

Figure 5. Example of Thesis in a Pre-Intervention Essay

Figure 5 illustrates the common pathway of introduction development for an expository essay proposed by Rose and Martin (2012); according to them, the introduction of this type of essay has to do with a Thesis divided into a preview and the position. This example shows an effective development of a Thesis in the pre-intervention essay.

Regarding the Arguments per se, four of the exposition essays had two paragraphs devoted to the body of the essay, while the other six essays had three paragraphs; different topics were presented with their elaborations in each paragraph. However, most elaborations were not clearly supported, or relevant information was omitted as shown in Figure 6.

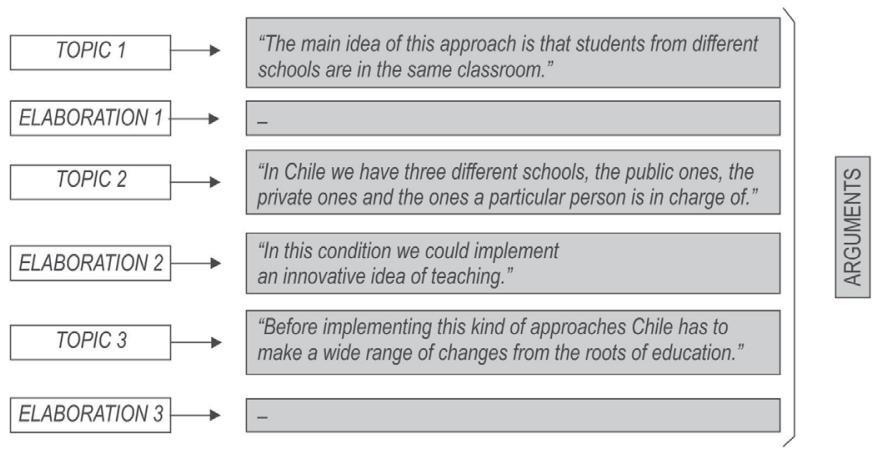

Figure 6. Example of Arguments in a Pre-Intervention Essay 
As illustrated in Figure 6, elaboration of topics of each of the three paragraphs and Arguments is not well-supported by accurate information or content presented. At the same time, Arguments do not follow a clear sequence of ideas because there is not a guiding threat to connect the ideas and make them coherent.

With respect to the Restatement, the ten essays had the last paragraph devoted to it; however, all of them were not complete because they missed either the review or the restatement, which according to Rose and Martin (2012) are fundamental in this text. This last paragraph is the less developed one by the students as the example shown in Figure 7.

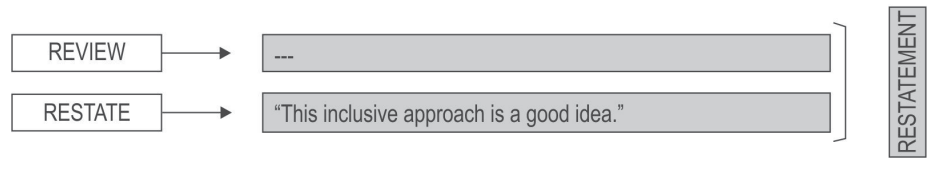

Figure 7. Example of Restatement in a Pre-Intervention Essay

Figure 7 shows that the last paragraph is not accurately developed as it lacks the review of the information presented in the text. The restate is a vague opinion which is not supported with evidence. In the general analysis, the Restatement was the less worked by the students because the content and supporting information were omitted.

Regarding the post-intervention essays, the ten post-intervention expository essays included a Thesis, Arguments, and Restatement with the different moves of information in each stage. This represents a substantial improvement in the schematic structure of the texts in comparison to the pre-intervention essays which lacked some moves especially in terms of elaboration of arguments in the body paragraphs of the essays and in the conclusion or restatement paragraphs.

With respect to moves within the three parts of the schematic structure in the postintervention exposition essays, they improved in comparison to the pre-intervention texts. Concerning the introductory paragraphs in the post-intervention essays, all the expository essays contained the two moves within this stage of the schematic structure of the text, which according to Rose and Martin (2012), represent the flow of information in the text. Figure 8 shows how information flows in the thesis paragraph of a postintervention essay.

Figure 8 illustrates that the Thesis of the example essay is complete. The two parts of the first paragraph in an expository essay are present, well-developed, and supported; the preview presents background information related to the topic at issue and the position shows the author's opinion regarding the topic at issue. 


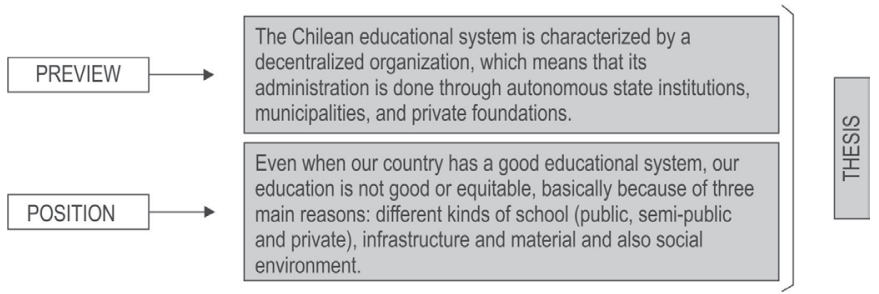

Figure 8. Thesis in a Post-Intervention Essay

In relation to the body of the essays, all the paragraphs had a clear topic with their respective elaboration; the elaboration of ideas was clear and supportive, different from the pre-intervention essays where topics were not evidently elaborated, information was omitted, or extra information was needed to support the topics at issue. Figure 9 illustrates how information flows in a post-intervention essay at the level of the arguments.
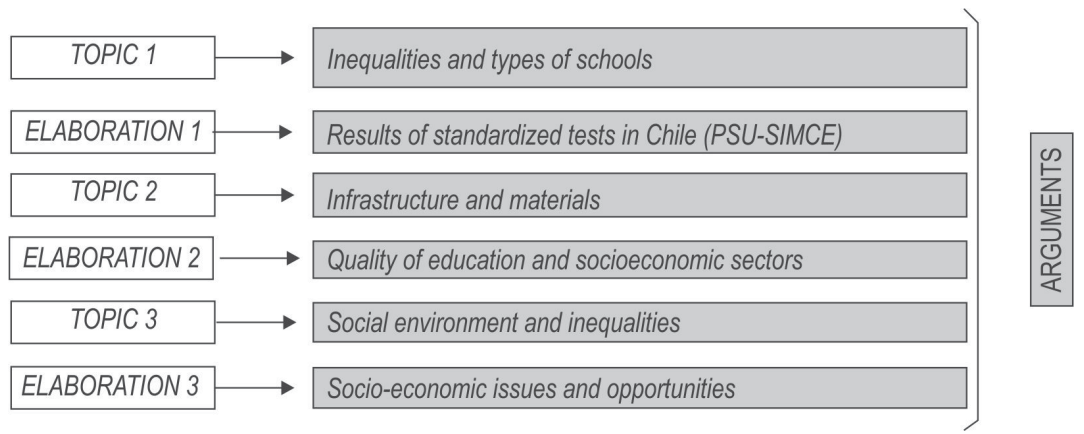

Figure 9. Example of Arguments in a Post-Intervention Essay

Figure 9 shows that the expository essay follows the moves in the Arguments. There are three topics with three elaborations which are essential in order to follow the development of the information in a text.

Finally, the concluding paragraphs summarized the standpoint at issue through the Review and the Restate of the main contents and topics developed in the essays. Postintervention expository essays had a better quality in the conclusions because all the ten texts included the Review and the Restate of the information. Figure 10 represents how information was summarized in the Restatement paragraph of a post-intervention essay. 

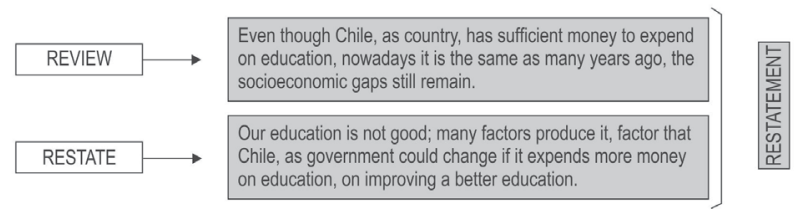

Figure 10. Examples of Restatement in Post-Intervention Essay

Figure 10 illustrates that the Restatement in the expository essay includes the two components, namely: review and restate. The review has a short summary of the background and supporting information presented in the essay and the restate is composed of the summary of the author's position and opinion presented in the Thesis of the essay.

All in all, the post-intervention essays accomplished all the moves in the genre of exposition proposed by Martin and Rose (2007) and Rose and Martin (2012). Expository essays written by the participants after the intervention period were enriched in terms of the schematic structure of the genre because students included all the different moves of information to develop their texts.

Finally, the characteristics of the post-intervention essays reflect that they improved in comparison to the pre-intervention tasks where the students did not include some moves. This improvement shows that the intervention period was effective and meaningful for participants, that is, a genre-based approach to writing produced a positive impact on the production of written expositions, and therefore, it was successful.

Based on the genre-based perspective the three stages applied during the intervention process, deconstruction, joint construction, and individual construction, supported the proper elaboration of the essays because "all forms of language development, whether spoken or written, depend on modelling and repetition; this is how we learn language" (Rose \& Martin, 2012, p. 77). It is to say, the stages of deconstruction and joint construction are essential when developing any genre, and in this case, these stages reinforced the individual construction of expository essays.

\section{Conclusion and Recommendations}

This paper aimed at describing and discussing an action research project based on a teaching approach to tackle expository essay writing. Participants were ten undergraduate students of English pedagogy at a public university in Chile; they were exposed to a teaching methodology centered on a genre-based approach to teaching writing based on three stages: deconstruction, joint construction, and individual construction adapted from Feez (1998), 
Bhatia (2004), Bawarshi and Reiff (2010), and Rose and Martin (2012) in a period of eight sessions of ninety minutes each.

After the analysis of writing tasks and teacher's log, results showed that a genre-based approach to writing expository essays is effective because participants improved their compositions after the intervention period. The different moves of the expository essay were considered, namely, thesis, arguments, and restatements with all the moves in each stage in the post-intervention essays.

Concerning the limitations during the research, the most important issue is related to the short period of instruction participants had. These eight sessions of ninety minutes were clearly effective, but more lessons devoted to deconstruction of texts, and negotiation of different features in the genres are necessary in order to give students more opportunities to be in contact with real texts and to take over these features. The necessity of more sessions is relevant because modeling and repetition are essential in language development (Rose \& Martin, 2012), that is, the first stage of deconstruction is the basis of the joint construction and individual construction of texts.

Regarding the implications of this research, a socio-semiotic approach to teaching writing represents a crucial method to use in a foreign language setting. Genre-based approaches provide resources about the way genres are construed in different communities. Bearing in mind that writing is a social activity, one sees that this methodology helps EFL students who do not have more contact with authentic texts than the opportunities provided by instructors. Therefore, a genre-based approach represents a compelling opportunity to help foreign language students to write different texts based on the analysis and evaluation of model genres and the joint construction of them.

As a recommendation, it would be interesting in the future to carry out research related to the use of resources of discourse such as appraisal, negotiation, and periodicity at the clause and sentence level in order to enrich discourse. At the same time, proper ways of negotiating attitudes in the text are essential to inform the students since writing represents an epistemic and recursive activity which conveys meanings (Gómez Burgos, 2015) and can be modified frequently based on analysis and evaluations of meanings discussed with the intended audience.

Finally, participants in this action research project were able to develop argumentative skills in writing because their expository essays improved after the period of instruction. Therefore, the impact of a genre-based approach to writing in the production of expository essays in these ten undergraduate students of English Pedagogy was very positive and meaningful. Hence, the genre-based approach to writing in a foreign language is an effective model to follow at university levels where students need to be instructed according to the different genres they are supposed to use in their professions. Writing has to be a meaning 
making process which gives learners linguistic resources to select and organize specific lexicogrammatical patterns to apply in different situations according to the meaning potential they possess.

\section{References}

Arancibia Aguilera, M. C. (2014). The design of a rubric to evaluate laboratory reports in Astronomy: Academic literacy in the disciplines. PROFILE Issues in Teachers' Professional Development, 16(1), 153-165. http://doi.org/10.15446/profile.v16n1.37232.

Bacha, N. N. (2010). Teaching the academic argument in a university EFL environment. Journal of English for Academic Purposes, 9(3), 229-241. http://doi.org/10.1016/j.jeap.2010.05.001.

Bawarshi, A., \& Reiff, M. J. (2010). Genre: An introduction to history, theory, research, and pedagogy. West Lafayette, US: Parlor Press.

Bhatia, V. K. (1993). Analysing genre: Language use in professional settings. London, UK: Longman.

Bhatia, V. K. (2004). Worlds of written discourse: A genre-based view. London, UK: Continuum.

Bloor, T., \& Bloor, M. (2004). The functional analysis of English. A Hallidayan approach. London, UK: Arnold.

Brisk, M. E. (2015). Engaging students in academic literacies: Genre-based pedagogy for K-5 classrooms. London, UK: Routledge.

Bruce, I. (2008). Academic writing and genre: A systematic analysis. New York, US: Continuum.

Chala, P. A. \& Chapetón, C. M. (2013). The role of genre-based activities in the writing of argumentative essays in EFL. PROFILE Issues in Teachers' Professional Development, 15(2), 127-147.

Davies, W. M. (2008). Not quite right: Helping students to make better arguments. Teaching in Higher Education, 13(3), 327-340. http://doi.org/10.1080/13562510802045352.

Díaz, Á. (2002). La argumentación escrita [Written argumentation]. Medellín, CO: Editorial Universidad de Antioquia.

Education First. (2013). English Proficiency Index (3rd ed.). México, MX: Author.

Feez, S. (1998). Text-based syllabus design. Sydney, AU: National Centre for English Language Teaching and Research.

Ferretti, R. P., Andrews-Weckerly, S., \& Lewis, W. E. (2007). Improving the argumentative writing of students with learning disabilities: Descriptive and normative considerations. Reading \& Writing Quarterly, 23(3), 267-285. http://doi.org/10.1080/10573560701277740.

Gómez Burgos, E. (2015). First year university students' use of formulaic sequences in oral and written descriptions. PROFILE Issues in Teachers' Professional Development, 17(1), 25-33. http:// doi.org/10.15446/profile.v17n1.43438.

Halliday, M. A. K., \& Hasan, R. (1985). Language, context, and text: Aspects of language in a social-semiotic perspective. Oxford, UK: Oxford University Press. 
Halliday, M. A. K., \& Matthiessen, C. M. (2004). Introduction to functional grammar. London, UK: Edward Arnold.

Harmer, J. (2001). The practice of English language teaching. Cambridge, UK: Longman.

Hyland, K. (2002). Genre: Language, context, and literacy. Annual Review of Applied Linguistics, 22, 113-135. http://doi.org/10.1017/s0267190502000065.

Hyland, K. (2007). Genre pedagogy: Language, literacy and L2 writing instruction. Journal of Second Language Writing, 16(3), 148-164. http://doi.org/10.1016/j.jslw.2007.07.005.

Hyon, S. (1996). Genre in three traditions: Implications for ESL. TESOL Quarterly, 30(4), 693-722. http://doi.org/10.2307/3587930.

Knapp, P., \& Watkins, M. (2005). Genre, text, grammar: Technologies for teaching and assessing writing. Sydney, AU: UNSW Press.

Martin, J. R., \& Rose, D. (2007). Working with discourse: Meaning beyond the clause (2nd ed.). London, UK: Continuum International Publishing Group.

Matthiessen, C. (2009). Meaning in the making: Meaning potential emerging from acts of meaning. Language Learning, 59, Suppl. 1, 206-229. http://doi.org/10.1111/j.14679922.2009.00541.x.

McCutchen, D. (2011). From novice to expert: Implications of language skills and writing: Relevant knowledge for memory during the development of writing skill. Journal of Writing Research, 3(1), 51-68. http://doi.org/10.17239/jowr-2011.03.01.3.

MINEDUC. (2012). Bases curriculares: lenguaje y comunicación [Curricular foundations: Language and communication]. Santiago, CL: Author.

Nunan, D. (1999). Second language teaching and learning. Australia: Heinle Cengage Learning.

Paltridge, B. (1996). Genre, text type, and the language learning classroom. ELT Journal, 50(3), 237-243. http://doi.org/10.1093/elt/50.3.237.

Paltridge, B. (2001). Genre and the language learning classroom. Ann Arbor, US: University of Michigan Press. http://doi.org/10.3998/mpub.23749.

Ramage, J., Callaway, M., Clary-Lemon, J, \& Waggoner, Z. (2009). Argument in composition. West Lafayette, US: Parlor Press.

Rose, D., \& Martin, J. R. (2012). Learning to write, reading to learn: Genre, knowledge and pedagogy in the Sydney school. Sheffield, UK: Equinox.

Wingate, U. (2006). Doing away with "study skills". Teaching in Higher Education, 11(4), 457-469. http://doi.org/10.1080/13562510600874268.

Wingate, U. (2012). Argument! Helping students understand what essay writing is about. Journal of English for Academic Purposes, 11(2), 145-154. http://doi.org/10.1016/j.jeap.2011.11.001.

Yasuda, S. (2015). Exploring changes in FL writers' meaning-making choices in summary writing: A systemic functional approach. Journal of Second Language Writing, 27, 105-121. http://doi. org/10.1016/j.jslw.2014.09.008. 


\section{The Author}

Eric Gómez Burgos holds an MA in applied linguistics to the teaching of English. Currently he works at Universidad de Talca in Linares (Chile) as the Director of the undergraduate English teacher program. His areas of interest are L2 writing and EFL teaching methodology.

\section{Acknowledgements}

I would like to thank Dr. Cristina Arancibia Aguilera from the Department of Linguistics at Universidad Católica de Chile for her valuable feedback and continuous support for the undertaking of my dissertation research summarized in part in this paper. 